\title{
TREATMENT OUTCOMES IN POSTPARTUM ANOESTRUS COWS GUIDED BY TRANSRECTAL ULTRASONOGRAPHY
}

\author{
M. R. Islam, N. S. Juyena ${ }^{1 *}$, M. M. U. Bhuiyan, M. M. Rahman and \\ R. N. Ferdousy \\ Department of Surgery and Obstetrics, Bangladesh Agricultural University \\ Mymensingh-2202, Bangladesh
}

\begin{abstract}
Anoestrus is considered as one of the most prevalent reproductive disorders in dairy cows and may occur due to hormonal imbalance, nutritional deficiency and disease conditions. Proper diagnosis and treatment are essential to overcome this disorder to make dairy herd profitable. Therefore, the aim of study was to determine effects of hormonal and nutritional treatments on induction of oestrus and conception in postpartum anoestrus cows. Effects of BCS and parity of anoestrus cows were also considered during treatment. Seventy two cross-breed cows having $\geq 60$ days postpartum period were used, which were allotted for two treatment groups. Forty cows were treated with hormone (GnRH and $\left.\mathrm{PGF}_{2} \alpha\right)$ and rest 32 cows were with nutritional supplement. AI was performed in cows in observed oestrus and the conception was determined by transrectal ultrasonography between 28-35 days post-Al. $75 \%$ cows showed oestrus in hormonal treatment groups whereas $56.3 \%$ cows in nutritional treatment group. Moreover, the conception rate was significantly $(\mathrm{P}<0.05)$ higher in cows $(57.5 \%)$ received hormonal treatment compared to that of cows $(40.6 \%)$ in nutritional treatment counterpart. Highest conception rate was also observed $(69.2 \%)$ in GnRH treated cows having BCS 2-2.5. Cows with parity 1-3 responded better to treatment and had higher conception rate. These results suggest that diagnosis of ovarian activities and reproductive disorders with the help of ultrasonography can lead to use appropriate techniques for treatment as well as to improve reproductive efficiencies of cows in case of postpartum anoestrus.
\end{abstract}

Key Words: Cows, GnRH, PGF 2 , Postpartum Anoestrus, Ultrasonography

\section{INTRODUCTION}

Fertility and breeding efficiency of dairy animals play a pivotal role in dairy economics (Peter et al., 2009). Any deviation in the breeding rhythm results in a progressive economic loss due to widening of dry period during the life span of animal (Dudhatra et al., 2012). Anoestrus is a period of sexual quietude in which the animal fails to exhibit normal oestrus cycles and no manifestation of heat (Boyd, 1977) and it is one of the major causes of

\footnotetext{
1 Associate Professor, Department of Surgery and Obstetrics, Bangladesh Agricultural University, Mymensingh-2202, Bangladesh

*Corresponding author (Email: juyenahabib@yahoo.com)
} 
economic losses in both the dairy and beef industries. Cows are regarded as physiologically anoestrous for a few days (up to 60) following parturition, whereas, lack of oestrus after 60 days postpartum is termed pathological anoestrus. Several attempts have been made to improve postpartum reproductive efficiency, including monitoring of ovarian activity by observing ovarian activity by ultrasound scanner. Various hormonal treatment have also been used to overcome anoestrus. Khair (2005) reported that ovsynch treatment using GnRH and $\mathrm{PGF}_{2 \alpha}$ can obtain $60 \%$ conception rate in anoestrus cows. Despite all these efforts, postpartum infertility is still a significant problem in dairy herds due to lacking of effective procedures for diagnosis and management of postpartum anoestrus in cows in Bangladesh. In routine clinical practice of commercial dairy farms, ultrasound scanning (US) has been reported to be an accurate and reliable method of observing dynamic changes in ovarian structures (Rajamahendran et al., 1994) and determining the patterns of postpartum resumption of ovarian activity, silent oestrus, anoestrus and cystic ovarian conditions, and thus, useful in reducing the calving interval (Rajamahendran and Taylor, 1990). Unfortunately, there are few studies on the use of transrectal ultrasonography as a diagnostic tool for reproductive disorders in Bangladesh. Therefore, the study was aimed to evaluate the effectiveness of US monitoring-based diagnosis and subsequent treatments of reproductive disorder on postpartum reproductive efficiency and to compare the efficacy of hormonal and nutritional treatments for induction of oestrus and conception in cows in postpartum anestrus. Moreover, effects of BCS and parity on the treatment of cows in postpartum anestrus were also monitored.

\section{METHODOLOGY}

The investigation was conducted in some registered farms of the Community- based Dairy Veterinary Foundation (CDVF), Department of Surgery and Obstetrics, Bangladesh Agricultural University, Mymensingh, from September 2011 to June 2012.Seventy two crossbred dairy cows with the complaint of postpartum anestrus ( $\geq 60$ days) were selected from 25 dairy farms located at Potiya Upazilla of Chittagong district. All cows calved normally and had no history of periparturient diseases or disorders. Routine deworming against round worms and liver flukes was in practice and the cows were vaccinated routinely against foot and mouth disease, anthrax and hemorrhagic septicemia. All cows were housed almost 24 hours in their rearing sheds having the facilities of natural ventilation and were fed concentrate, green grasses, straw and water ad-libitum. The number of parity and ages of cows were determined by interviewing the farmers and by dental examination of cows, respectively. The nutritional status of the cows were determined through BCS by scoring the body conditions of the cows using 1-5 scales (0.5 fraction between 2 scores) on the basis of bony prominence and deposition of subcutaneous fat as described by Nicholson and Butterworth (1986). The hormonal treatment was given to 40 cows having cyclicity confirmed by using transrectal ultrasonography on the basis of presence or absence of follicle and corpus luteum (CL). Another 32 cows were treated with nutritional supplement without monitoring by US and grouped in nutritional treatment. 
Among 40 anestrous cows, 17 cows without CL were treated with a single dose of GnRH analogue and $\mathrm{PGF}_{2 \alpha}$ was administered into 23 cows with $\mathrm{CL}$.

\section{Examination of genital organs of cows by ultrasonography}

The reproductive structures were monitored at three days intervals by real time B-mode ultrasonography using a transrectal probe (with $5 \mathrm{MHz}$ frequency transducer) and ultrasound machine (Phar Vision Micro V10, Classic Medical Supply, Inc., USA) to observe two consecutive estrous cycles. The linear probe was inserted into the rectum and moved forward over the vagina through the rectum to place it lateral to the cervix. Specific changes on the cervix were identified. Then the body and horn of the uterus was examined and changes were recorded. Follicles greater than or equal to $5 \mathrm{~mm}$ in diameter were recorded. Ovarian pictures were recorded on the video recorder attached to the scanner (Fig. 1). Numbers and sizes of ovarian follicles were determined at every three days and follicles with a diameter $9-16 \mathrm{~mm}$ present on the ovaries at Day 6 to 15 were assumed to be the dominant follicles of the interovulatory cycle (Fig. 2). Follicles with a diameter of 17 to 19 $\mathrm{mm}$ subsequently seen at Day 18 to Day 0 (day of ovulation) were considered to be ovulatory follicles. Ovulation was determined by the disappearance of the dominant follicles. Onset of atresia of follicles were considered the day from which follicles began regressing in size. The development and regression of the corpus luteum (Fig. 3) and other ovarian changes, such as follicle development, were carefully noted and recorded.

\section{Treatment protocol}

For hormonal treatment, 40 cows were selected on the presence of $\mathrm{CL}$ and follicles observed by ultrasonography. GnRH analogue (Each $\mathrm{ml}$ contain $100 \mu \mathrm{g}$ synthetic gonadorelin, Fertilon ${ }^{\circledR}$, Techno Drugs Bangladesh Ltd., Dhaka) and PGF $_{2 \alpha}$ (Each ml contain 250 mcg Cloprostenol, Ovuprost ${ }^{\circledR}$, Renata Drugs Bangladesh Ltd., Dhaka) hormones were used. Cows having small follicles were given single intramuscular (IM) injection of $500 \mu \mathrm{g} \mathrm{GnRH}$ analogue and cows having CL were treated with single intramuscular (IM) injection of $2 \mathrm{ml}$ $\mathrm{PGF}_{2 \mathrm{\alpha}}$ analogue. Rest 32 cows were provided with nutritional supplement as balanced diet (Maize, Wheat bran, Oil cake, Rice polish, Vitamine-Mineral premixes, anthelmintics) with monitoring the reproductive organs by ultrasonography.

Cows showed oestrus behaviour was inseminated by skilled AI technicians using frozen semen. Oestrus was detected by the farmers on the basis of clinical manifestation of oestrus signs. The cows were examined by transrectally ultrasonography for pregnancy diagnosis between 28-35 days (Fig. 4) after AI and results were recorded.

\section{Statistical analysis}

Statistical analysis was performed for the data recorded on cow's information and response to treatment with respect to induction of cyclicity and conception. Post Hoc Test using SPSS ${ }^{\circledR}$ software was used. The difference between values was considered significant when the $P$ value was less than 0.05 . 


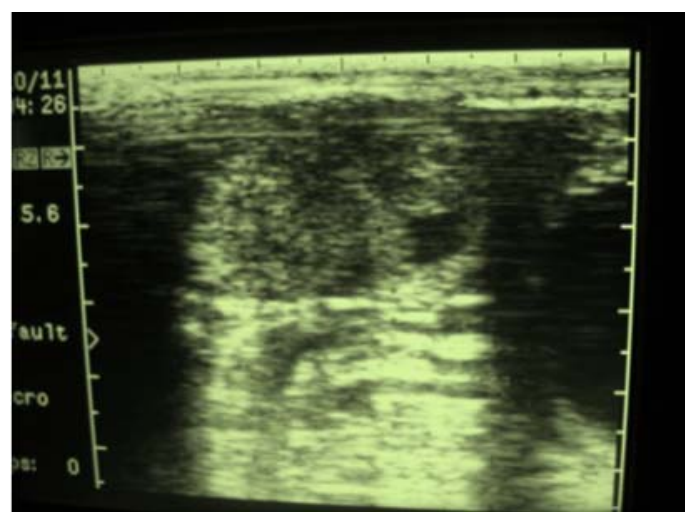

Fig. 1. Ultrasonographic image of ovary of cows

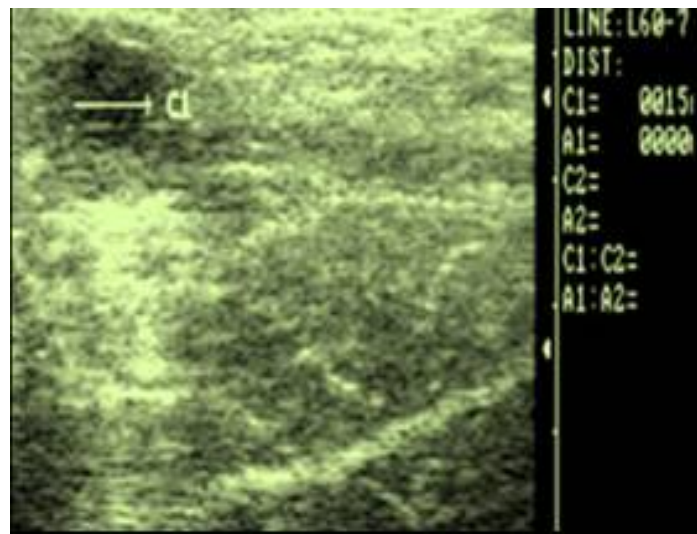

Fig. 3. Ultrasonographic image of corpus luteum of cows

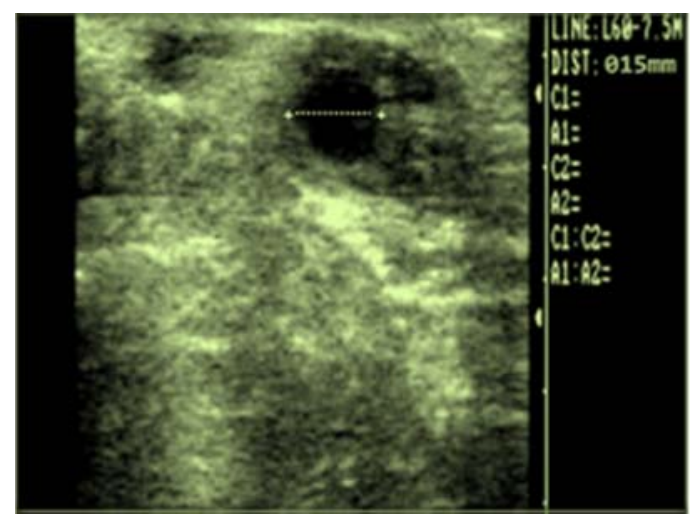

Fig. 2. Ultrasonographic image of pre-ovulatory follicle of cows

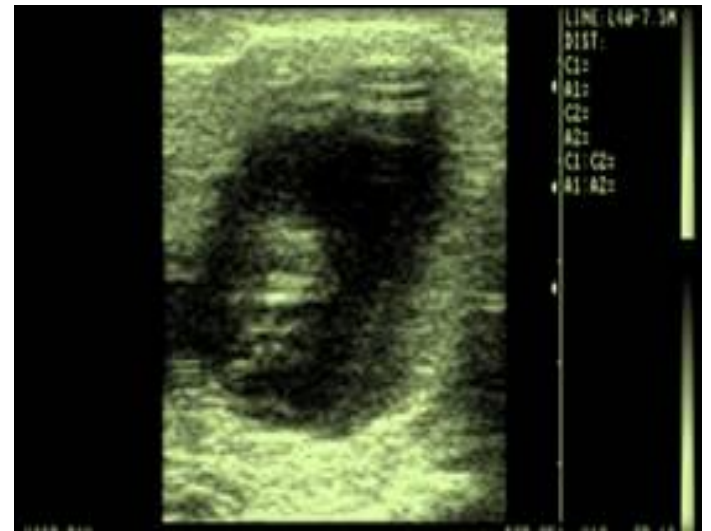

Fig. 4. Embryo of 35 days pregnant cows (Ultrasonographic image)

\section{RESULTS AND DISCUSSION}

Successful economy of a dairy farm production lies in ensuing proper and optimal reproductive rhythm of individual cow within the normal physiological range. Anoestrus not only does lengthen the postpartum interval, but also substantially reduce the farmer's financial returns from milk or beef sales. Considering this perspective the study was aimed to evaluate the effectiveness of US monitoring-based diagnosis and subsequent treatments of post/partum anoestrus. Effects of hormones and nutrition on post-partum anoestrus cows are shown in Table 1. It showed that when hormonal treatment was given for induction of oestrus, higher $(75.0 \%)$ proportion of cows showed oestrus compared to nutritional treatment counterpart (56.3\%). In addition, $57.5 \%$ cows conceived after receiving hormonal treatment. The difference in the induction of oestrus and conception rate in cows between hormonal and nutritional treatment was statistically significant $(\mathrm{P}<0.05)$.

We studied effects of two hormones on oestrus induction and conception in cows, and results are shown in Table 2. It shows that the higher proportion of cows showed oestrus 
(76.5\%) and conceived (64.7\%) after receiving treatment with GnRH than cows received treatment with $\mathrm{PGF}_{2 \mathrm{a}}$. The difference in conception rate between cows received two hormonal treatments was statistically significant $(\mathrm{P}<0.05)$.

Table 1. Effects of hormonal and nutritional treatment of postpartum anoestrus cows for induction of oestrus and conception

\begin{tabular}{c|c|c|c|c|c}
\hline Treatment & $\begin{array}{c}\text { Number of } \\
\text { cows treated }\end{array}$ & $\begin{array}{c}\text { Number of } \\
\text { cows showed } \\
\text { oestrus }\end{array}$ & $\begin{array}{c}\text { \% cows showed } \\
\text { oestrus }\end{array}$ & $\begin{array}{c}\text { No. of cows } \\
\text { conceived }\end{array}$ & $\begin{array}{c}\% \text { Cows } \\
\text { Conceived }\end{array}$ \\
\hline Hormonal & 40 & 30 & $75.0^{\mathrm{a}}$ & 23 & $57.5^{\mathrm{a}}$ \\
Nutritional & 32 & 18 & $56.3^{\mathrm{b}}$ & 13 & $40.6^{\mathrm{b}}$ \\
\hline
\end{tabular}

$\mathrm{a}, \mathrm{b}$ indicate significant difference $(\mathrm{P}<0.05)$ between two groups

Table 2. Effects of two hormonal treatments on for induction of oestrus and conception in postpartum anoestrus cows

\begin{tabular}{lccccc}
\hline Treatment & $\begin{array}{c}\text { Number of } \\
\text { cows } \\
\text { treated }\end{array}$ & $\begin{array}{c}\text { Number of } \\
\text { cows showed } \\
\text { oestrus }\end{array}$ & $\begin{array}{c}\text { \% cows showed } \\
\text { oestrus }\end{array}$ & $\begin{array}{c}\text { Number of } \\
\text { cows conceived }\end{array}$ & $\begin{array}{c}\text { \% cows } \\
\text { conceived }\end{array}$ \\
\hline GnRH inj & 17 & 13 & 76.5 & 11 & $64.7^{\mathrm{a}}$ \\
PGF $_{2 \alpha}$ inj & 23 & 17 & 73.9 & 12 & $52.1^{\mathrm{b}}$ \\
\hline
\end{tabular}

$\mathrm{a}, \mathrm{b}$ indicate significant difference between groups $(\mathrm{P}<0.05)$

Previous studies showed that the ovulation in response to GnRH treatment in postpartum in cattle it was $85 \%$ (Wiltbank et al., 1997). In the present study interval after GnRH to ovulation was $48 \mathrm{~h}$ while, 30-32 h has been reported in cattle (Pursley et al., 1995). Lack of ovarian activity or true anoestrus is considered as one of the major problems to efficient cattle reproduction and cows with true anoestrus may have complete ovarian inactivity (Mcleod and Williams, 1991). Rahman (2010) demonstrates that cows with true anoestrus by 60 days postpartum need to have some sort of management or hormonal interventions for induction of cyclicity and conception. Accordingly, the present study has demonstrated that a single injection of GnRH analogue has positive effect on induction of oestrus and conception in anoestrus cows. GnRH and its agonist act on ovarian follicular development and CL formation indirectly via the induced release of pituitary LH and FSH. Administration of $\mathrm{GnRH}$ causes the large follicles to ovulate and induces emergence of a new follicular wave within 3 to 4 days after treatment at any stage of the oestrous cycle in cattle. We also observed that $(73.9 \%)$ cows showed estrus when PGF $_{2 \alpha}$ was used. Dudhatra et al. (2012) have demonstrated that administration of $\mathrm{PGF}_{2 \alpha}$ or their analogues in early postpartum cows hasten early resumption of cyclic ovarian activity and thereby, increased the reproductive efficiency.

\section{Effect of BCS and parity with the treatment regimen in postpartum anoestrus cows}

Effect of BCS of cow on the different treatments are shown in Table 3. BCS is widely used for the evaluation of nutritional status of animals, which influences the fertility indexes. It 
was found that higher $(77.8 \%)$ proportion of cows showed oestrus after receiving treatment with $\mathrm{PGF}_{2 \alpha}$ when their BCS ranged 2.0-2.5. After AI, conception rate was higher $(69.2 \%)$ in cows with BCS 2.0-2.5 treated with GnRH. In contrast, 47.6\% cows with BCS 1.5-2.0 showed oestrus behavior after nutritional treatment as well as conception rate was lower (33.3\%) in this group. There is paucity of research to compare our findings in this regard.

Table 3. Effects of BCS on hormonal and nutritional treatment in post-partum anoestrus cows

\begin{tabular}{l|c|c|c|c|c|c}
\hline Treatment & $\begin{array}{c}\text { Body } \\
\text { condition } \\
\text { score (range) }\end{array}$ & $\begin{array}{c}\text { Number of } \\
\text { cows treated }\end{array}$ & $\begin{array}{c}\text { Number of } \\
\text { cows } \\
\text { showed } \\
\text { oestrus }\end{array}$ & $\begin{array}{c}\text { \% cows } \\
\text { showed } \\
\text { oestrus }\end{array}$ & $\begin{array}{c}\text { Number of } \\
\text { cows } \\
\text { conceived }\end{array}$ & $\begin{array}{c}\% \text { cows } \\
\text { conceived }\end{array}$ \\
\hline GnRH. & $2.0-2.5$ & 13 & 10 & $76.9^{\mathrm{a}}$ & 9 & $69.2^{\mathrm{a}}$ \\
& $3.0-3.5$ & 4 & 2 & $50.0^{\mathrm{b}}$ & 2 & $50.0^{\mathrm{b}}$ \\
\hline PGF $_{2 \alpha}$ & $2.0-2.5$ & 18 & 14 & $77.8^{\mathrm{a}}$ & 9 & $50.0^{\mathrm{b}}$ \\
\hline Nutritional & $2.5-3.5$ & 5 & 3 & $60.0^{\mathrm{c}}$ & 3 & $60.0^{\mathrm{a}}$ \\
\hline
\end{tabular}

$a, b, c$ indicate significant difference between groups $(\mathrm{P}<0.05)$

The study determined the effect of parity of animals on induction of cyclicity and conception in postpartum anoestrus crossbred cows and results are showed in Table 4. It showed that the highest proportion of cows with parity range 1-3 showed oestrus $(76.9 \%)$ and conception rate $(69.2 \%)$ after receiving treatment with $\mathrm{GnRH}$. Induction of oestrous and conception were lower in cows with parity range 4-5 in nutritional treatment group. But the variation was insignificant. Contrasting to the present finding, it has been reported that parity has positive influence on onset of postpartum cyclicity in bovine (Williams and Amstalden, 2000). The difference in cyclicity between investigations may be due to differences in number of animals studied between two investigations. Moreover, Tanaka et al. (2007) reported a significant relationship between parity and days to first ovulation after calving in bovine.

Interrelationship between nutrition and reproductive performance of dairy heifers cannot be ignored and this interrelationship has far reaching effects on the physiological functioning of the reproductive system, which is constantly under the influence of the endocrine system. However, the mechanism by which nutrition influences reproduction in bovine has not been fully established.

We used transrectal ultrasonography for determination of cyclicity and pregnancy of cows. The technique is noninvasive, relatively simple and effective; safe to both the subject and the operator, portable and ultrarapid, and it facilitates immediate interpretation and diagnosis in most circumstances. Our results support that ultrasonography can be effectively used to monitor follicular dynamics and oestrus accurately. Moreover, proper 
synchronization procedure can be taken, which could help to improve reproductive efficiency of dairy cows.

Table 4. Effect of parity on hormonal and nutritional treatment in postpartum anoestrus cows

\begin{tabular}{l|c|c|c|c|c|c}
\hline $\begin{array}{c}\text { Treatment } \\
\text { type }\end{array}$ & $\begin{array}{c}\text { Parity of } \\
\text { cows }\end{array}$ & $\begin{array}{c}\text { Number of } \\
\text { cows treated }\end{array}$ & $\begin{array}{c}\text { Number } \\
\text { of cows } \\
\text { showed } \\
\text { oestrus }\end{array}$ & $\begin{array}{c}\text { \% cows } \\
\text { showed } \\
\text { oestrus }\end{array}$ & $\begin{array}{c}\text { Number of } \\
\text { cows } \\
\text { conceived }\end{array}$ & $\begin{array}{c}\% \text { cows } \\
\text { conceived }\end{array}$ \\
\hline GnRH & $1-3$ & 13 & 10 & 76.9 & 9 & 69.2 \\
\hline PGF2a & $4-5$ & 4 & 3 & 75.0 & 2 & 50.0 \\
\hline Nutritional & $1-3$ & 19 & 14 & 73.6 & 10 & 52.6 \\
& $4-5$ & 4 & 3 & 75.0 & 2 & 50.0 \\
\hline
\end{tabular}

a, b, c indicate significant difference between groups $(\mathrm{P}<0.05)$

\section{CONCLUSIONS}

Treatment of postpartum anoestrus cows with hormones has positive effect on induction of oestrus followed by conception and GnRH may be the drug of choice. BCS and parity of cows influence the treatment outcome. Veterinarians may fail to detect oestrus by per rectal palpation of genital organs. Ultrasonography should be considered as a specific diagnostic aid for the clinical evaluation of ovarian activity as well as reproductive disorders, which could help to take proper curative measures.

\section{REFERENCES}

Boyd, H. 1977. Anoestrus in cattle. Veterinary Recordings, 100: 150-153.

Dudhatra, G. B., Mody, S. K., Patel, H. B., Modi, C. M., Chukewar, A. B., Kumar, A. and Awale, M. M. 2012. Prostaglandins and its Analogues: An approach for Treatment of Anoestrus and to enhance Breeding Efficiency, Vet. World., 5(6): 378-384.

Khair, A. 2005. Hormonal interventions to increase fertility in anestrous and repeat breeder cows. M.S. Thesis. Department of Surgery and Obstetrics, Faculty of Veterinary Science, Bangladesh Agricultural University, Mymensingh.

McLeod, B. J. and Williams, M. E. 1991. Incidence of ovarian dysfunction in postpartum dairy cows and the effectiveness of its clinical diagnosis and treatment. Veterinary Record., 128: 121-124.

Nicholson, M. J. and Butterworth, M. H. 1986. A guide to condition scoring of Zebu cattle. International Livestock Center for Africa, Addis Ababa, Ethiopia.

Peter, A. T., Vos, P. L. and Ambrose, D. J. 2009. Postpartum anoestrus in dairy cattle. Theriogenology, 71: 1333-1342. 
Pursley, J. R., Mee, M. O. and Wiltbank, M. C. 1995. Synchronization of ovulation in dairy cows using PGF2a and GnRH. Theriogenology, 44: 915-923.

Rahman, M. M. 2010. Management and effective treatment of postpartum anoestrus cows guided by ultrasonography. M. S. Thesis. Department of Surgery and Obstetrics, Faculty of Veterinary Science, Bangladesh Agricultural University, Mymensingh.

Rajamahendran, R. Ambrose, D. J. and Burton, B. 1994. Clinical and research applications of real-time ultrasonography in bovine reproduction: a review. Canadian Veterinary Journal, 35: 563-572.

Rajamahendran R. and Taylor, C. 1990. Characterization of ovarian activity in postpartum dairy cows using ultrasound imaging and progesterone profiles. Animal Reproduction Science, 22: 171-180.

Tanaka, T., Arai, M., Ohtani, S., Uemura, S., Kuroiwa, T., Kim, S. and Kamomae, H. 2007. Influence of parity on follicular dynamics and resumption of ovarian cycle in postpartum dairy cows. Animal Reproduction Science, 108: 134-43.

Williams, S. W. and Amstalden, M. 2000. Leptin gene expression, circulating leptin, and luteinizing hormone pulsatility are acutely responsive to short-term fasting in prepubertal heifers: Relationships to circulating insulin and insulin-like growth factor I. Biology of Reproduction, 63: 127-133.

Wiltbank, M. C. 1997. How information on hormonal regulation of the ovary has improved understanding of the timed breeding programs. In: Proceed. Annual Meeting of Society for Theriogenology, Montereal, Canada. 83-97. 